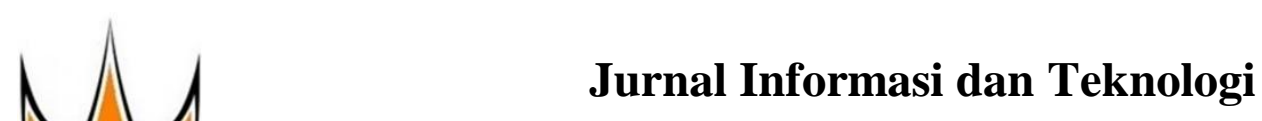

http://www.jidt.org

2021 Vol. $3 \quad$ No. $3 \quad$ Hal:134-138 ISSN: 2714-9730 (electronic)

\title{
Simulasi Monte Carlo Dalam Memprediksi Penerimaan Peserta Pelatihan Dasar CPNS
}

\author{
Faisal Roza $^{1 凶}$, Sarjon Defit ${ }^{2}$, Gunadi Widi Nurcahyo ${ }^{3}$ \\ ${ }^{1}$ PPSDM Regional Bukittinggi Kementerian Dalam Negeri \\ ${ }^{2,3}$ Universitas Putra Indonesia YPTK Padang \\ faisa1roza76@gmai1.com
}

\begin{abstract}
The implementation of basic training recruit (latsar) of civil servant (CPNS) at Pusat Pengembangan Sumber Daya Manusia (PPSDM) Ministry of Internal Affairs regional Bukittinggi. The leader takes decision in doing the implementation of latsar CPNS recruit in PPSDM scope regional Bukittinggi. Latsar CPNS is one of requirements to be civil servant. Therefore, it is necessary to collect data by doing observation, interview questionings with related party in the implementation of latsar CPNS recruit from 2018 to 2020 . It can be predicted for the next recruit. After doing library references by reading some books and journals, the basic training recruit of CPNS sources from PPSDM regional Bukittinggi, and Monte Carlo simulation. By using Monte Carlo simulation in predicting data, it can get closer value of actual value. Based on distribution of sampling data, the method is by choosing random numbers from probability distribution to do simulation. The Monte Carlo result's examination has got 173 participants for year 2019, 158 participants for year 2020, and 157 participants for year 2021 clearly. Although the rate of the accurate just reaches $81 \%$, but it has been able to be recommended to help PPSDM regional Bukittinggi, Ministry of Internal Affairs in taking decision and planning for basic training recruit of CPNS for the next.
\end{abstract}

Keywords: Simulation, Monte Carlo Method, Prediction, Calon Pegawai Negeri Sipil (CPNS), Pusat Pengembangan Sumber Daya Manusia (PPSDM).

\begin{abstract}
Abstrak
Penyelenggaraan penerimaan pelatihan dasar (latsar) Calon Pegawai Negeri Sipil (CPNS) di Pusat Pengembangan Sumber Daya Manusia (PPSDM) Regional Bukittinggi Kementerian Dalam Negeri. Pimpinan dapat mengambil keputusan dalam penyelenggaraan penerimaan latsar CPNS di lingkungan PPSDM Regional Bukittinggi. Latsar CPNS merupakan salah satu syarat di angkat menjadi Pengawai Negeri Sipil (PNS). Oleh karena itu di kumpulkan data melalui observasi, wawancara, tanya jawab dengan pihak terkait dalam penyelenggaraan penerimaan latsar CPNS dari tahun 2018 sampai dengan 2020 sehingga dapat memprediksi penerimaan latsar untuk tahun depan. Setelah peninjauan studi pustaka dengan membaca beberapa buku referensi serta jurnal-jurnal yang ada maka penerimaan peserta latsar CPNS bersumber dari PPSDM Regional Bukittinggi dengan simulasi Monte Carlo. Melalui simulasi Monte Carlo dalam memprediksi data, dapat menemukan nilai yang mendekati nilai aktual dari penerima peserta pelatihan dasar CPNS, berdasarkan distribusi data sampling. Metode ini yaitu dengan memilih angka acak dari distribusi probabilitas untuk melakukan simulasi. Hasil pengujian Monte Carlo telah dapat 173 peserta untuk tahun 2019, 158 peserta untuk tahun 2020 dan 157 peserta untuk tahun 2021 dengan jelas. Walaupun tingkat akurasinya baru $81 \%$, tetapi sudah dapat direkomendasikan untuk membantu PPSDM Regional Bukittinggi Kementeriaan Dalam Negeri dalam pengambilan keputusan dan perencanaan penerimaan peserta latsar CPNS yang akan datang.
\end{abstract}

Kata kunci: Simulasi, Monte Carlo, Prediksi, Calon Pegawai Negeri Sipil (CPNS), Pusat Pengembangan Sumber Daya Manusia (PPSDM).

\section{Pendahuluan}

Kemajuan teknologi informasi semakin pesat seiring dengan perkembang hardware dan software yang dikembangkan oleh perusahaan besar dunia. Kemajuan tersebut memberikan dampak yang signifikan terhadap kehidupan manusia. Banyak pekerjaan dalam kehidupan manusia menggunakan bantuan teknologi. Saat ini berbagai macam masalah dan aplikasi bidang bisnis, keuangan, teknik serta sains menerapkan metode Monte Carlo. Terlihat terlalu komplek yang dihitung secara analitis untuk solusi masalah tertentu. Berbagai bidang telah menerapkan simulasi Monte Carlo diantaranya, menghitung dan memprediksi tersebarnya hamburan cahaya yang di kirim ke neuron melalui jaringan saraf berpotensi terpengaruh [1].

Mempelajari keamanan dermaga bundar dan jembatan kereta api yang ada untuk mencapai keseimbangan antara keselamatan, fungsionalitas dan ekonomi [2]. Menghitung neutron skyshine dosisekuivalen dari akselerator linier electron $18 \mathrm{MeV}$ [3]. Simulasi Monte Carlo dari linac menggunakan PRIMO yaitu alat pendidikan ramah pengguna yang dapat di bawa ke cloud secara gratis [4]. Simulasi Monte Carlodalam 
memprediksi penerimaan latsar CPNS di PPSDM membutuhkan perencanaan yang matang dan pengambilan keputusan yang tepat. Pengambilan keputusan dalam memprediksi persediaandarah di masa datang [5].

Dalam mengolah 10 kegiatan yang ada pada proyek pembangunan jembatan gantung untuk mengatasi semua resiko dan ketidakpastian [6]. Pemilik usaha mengetahui keuntungan dan ketersediaan biaya dalam memproduksi [7]. Pengambilan kebijakan untuk meningkatkan rekomendasi pelayanan [8]. Menentukan jumlah persediaan barang berdasarkan data tahun sebelumnya [9]. Menentukan persediaan produk barang penjualan dan membantu manajemen perusahaan berdasarkan permintaan pasar [10]. Perkiraan hasil ujian nasional siswa pada tiga tahun terakhir [11]. Simulasi komputer memiliki dampak besar pada masyarakat di masa lalu dan akan terus berlanjut di masa depan [12].

Model tiruan dari suatu benda, sistem atau informasi nyata yang dianggap penting untuk ditelaah [13]. Memperkirakan cara kerja sistem yang ada dengan beberapa kondisi yang berbeda [14]. Meramalkan kebutuhan konsumen berupa barang atau jasa dalam menentukan harga, tempat dan waktu [15]. Ada lima tahapan yang dapat digunakan dalam simulasi [16]. Beberapa algoritma yang digunakan untuk membangkitkan bilangan acak [17].

\section{Metodologi Penelitian}

Pada metodologi penelitian terdapat langkah-langkah yang akan digunakan untuk menyelesaikan suatu permasalahan yang terjadi, permasalahan yang terjadi pada penelitian ini mengenai prediksi penerimaan peserta pelatihan dasar CPNS, dengan menggunakan metode Monte Carlo. Berikut tahapan-tahapan yang dapat digunakan pada metode Monte Carlo pada Gambar 1 .

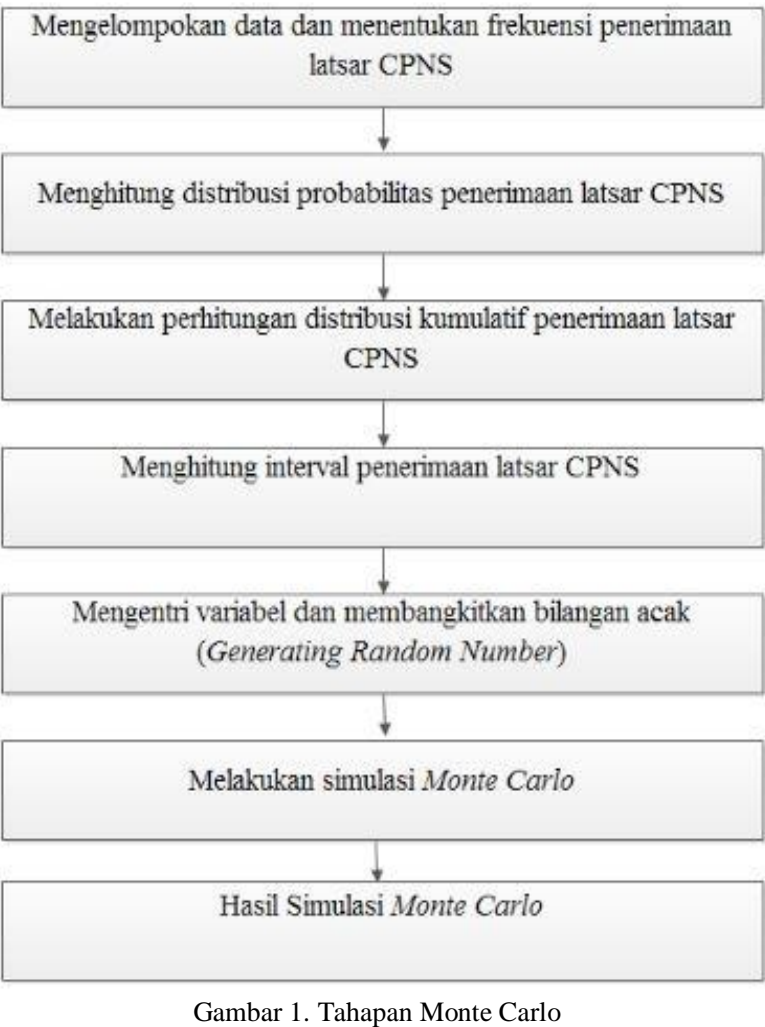

Berdasarkan Gambar 1 susunan tahapan metode Monte Carlo dapat di uraikan sebagai berikut:

a. Mengelompokan data dan menentukan frekuensi penerimaan latsar CPNS.

Pada penelitian ini data yang di pakai 3 tahun yaitu tahun 2018 sampai dengan 2020.

b. Menghitung distribusi probabilitas penerimaan latsar CPNS.

Distribusi probabilitas penerimaan latsar CPNS yang ditetapkan berpedoman kepada jumlah frekuensi penerimaan latsar distribusi probabilitas digunakan sebagai acuan dalam membuat distribusi kumulatif.

c. Melakukan perhitungan distribusi kumulatif penerimaan latsar CPNS.

Dalam melakukan perhitungan distribusi kumulatif penerimaan latsar CPNS berpedoman kepada distribusi probabilitas, distribusi kumulatif digunakan sebagai acuan dalam mengelompokan batasan interval.

d. Menghitung interval penerimaan latsar CPNS.

Untuk menghitung interval penerimaan latsar CPNS diperlukan ada 2 batasan interval yaitu batasan awal dan batasan akhir.

e. Mengentri variable dan membangkitkan bilangan acak (Generating Random Number). 
Pada tahapan ini akan dilakukan pembangkitan bilangan acak sebanyak 5 dengan mengentri variable bilangan acak tersebut.

f. Melakukan simulasi Monte Carlo.

Melakukan simulasi Monte Carlo berdasarkan angka acak yang didapatkan sebelumnya, maka angka acak tersebut dijadikan acuan dalam memprediksi penerimaan pelatihan dasar CPNS untuk tahun berikutnya.

\section{g. Hasil simulasi Monte Carlo.}

Hasil simulasi Monte Carlo dapat memprediksi penerimaan latsar CPNS tahun berikutnya yaitu tahun 2021.

\section{Hasil dan Pembahasan}

Hasil perhitungan data penerimaan latsar CPNS Purna Praja IPDN selama 3 tahun menggunakan metode Monte Carlo akan diuraikan pada pembahasan berikut ini.

a. Mengelompokan data dan menentukan frekuensi penerimaan latsar CPNS dengan data yang digunakan tahun 2018 sampai dengan 2020 seperti pada Tabel 1 .

Tabel 1. Data Penerimaan Latsar CPNS Tahun 2018 s/d 2020

\begin{tabular}{llccc}
\hline \multirow{2}{*}{ No } & \multicolumn{1}{c}{ Jurusan } & \multicolumn{3}{c}{ Frekuensi (orang) } \\
\cline { 2 - 5 } & \multicolumn{1}{c}{2018} & 2019 & 2020 \\
\hline 1 & Analis Keungan & 15 & 15 & 18 \\
2 & $\begin{array}{l}\text { Analis Sumber Daya } \\
\text { Manusia Aparatur }\end{array}$ & 21 & 20 & 23 \\
\multirow{2}{*}{3} & $\begin{array}{l}\text { Analis Kependudukan } \\
\text { dan Pencatatan Sipil }\end{array}$ & 36 & 33 & 33 \\
\multirow{2}{*}{4} & $\begin{array}{l}\text { Analis Pengembangan } \\
\text { Kapasitas Keuangan }\end{array}$ & 37 & 34 & 32 \\
& $\begin{array}{l}\text { Daerah } \\
\text { Analis Tata Praja }\end{array}$ & 47 & 41 & 43 \\
\hline & Jumlah & 156 & 143 & 149 \\
\hline
\end{tabular}

Dari Tabel 1 menyajikan data penerimaan latsar CPNS Purna Praja IPDN tahun 2018 sampai dengan 2020 berdasarkan jurusan serta dikelompokan berdasarkan distribusi frekuensi pertahun untuk memprediksi penerimaan latsar CPNS Purna Praja IPDN tahun 2019, tahun 2020 dan tahun 2021.

b. Menghitung distribusi probabilitas penerimaan latsar CPNS.

$$
D p(x)=\text { if/tof }
$$

Dimana $\boldsymbol{D} \boldsymbol{p}(\boldsymbol{x})$ merupakan distribusi probabilitas frekuensi, jf merupakan jumlah frekuensi dan tof berupa jumlah total frekuensi. Dapat dilihat pada Tabel 2.

$$
\begin{aligned}
& \mathrm{Dp}_{1}=15 / 156=0,10 \\
& \mathrm{Dp}_{2}=21 / 156=0,13 \\
& \mathrm{Dp}_{3}=36 / 156=0,23 \\
& \mathrm{Dp}_{4}=37 / 156=0,24
\end{aligned}
$$

\begin{tabular}{|c|c|c|c|}
\hline No & Jurusan & $\begin{array}{c}\text { Frekuensi } \\
2018 \\
\end{array}$ & $\begin{array}{c}\text { Distribusi } \\
\text { Probabilitas }\end{array}$ \\
\hline 1 & Analis Keungan & 15 & 0,10 \\
\hline 2 & $\begin{array}{l}\text { Analis Sumber Daya } \\
\text { Manusia Aparatur }\end{array}$ & 21 & 0,13 \\
\hline 3 & $\begin{array}{l}\text { Analis Kependudukan } \\
\text { dan Pencatatan Sipil } \\
\text { Analis Pengembangan }\end{array}$ & 36 & 0,23 \\
\hline 4 & $\begin{array}{l}\text { Kapasitas Keuangan } \\
\text { Daerah }\end{array}$ & 37 & 0,24 \\
\hline \multirow[t]{2}{*}{5} & Analis Tata Praja & 47 & 0,30 \\
\hline & Jumlah & 156 & 1,00 \\
\hline
\end{tabular}

$$
\mathrm{Dp}_{5}=47 / 156=0,30
$$

Total Dp $=0,10+0,13+0,23+0,24+0,30=1,00$

Tabel 2. Distribusi probabilitas penerimaan latsar CPNS Tahun 2018

c. Melakukan perhitungan distribusi kumulatif penerimaan latsar CPNS, dihasilkan dari jumlah distribusi probabilitas ditambah dengan jumlah distribusi probabilitas sebelumnya, kecuali distribusi kumulatif yang pertamasama dengan distribusi probabilitas awal dapat dilihat pada Tabel 3.

$$
\mathrm{J}_{\mathrm{k}}(\mathrm{x})=\mathrm{D}_{\mathrm{t}}(\mathrm{x})+\mathrm{D}_{\mathrm{t}-1}(\mathrm{x})(2)
$$

\begin{tabular}{|c|c|c|c|c|}
\hline No & Jurusan & $\begin{array}{c}\text { Frekuensi } \\
2018\end{array}$ & $\begin{array}{l}\text { Distribusi } \\
\text { Probabilitas }\end{array}$ & $\begin{array}{l}\text { Distribusi } \\
\text { Kumulatif }\end{array}$ \\
\hline 1 & $\begin{array}{l}\text { Analis } \\
\text { Keungan } \\
\text { Analis Sumber }\end{array}$ & 15 & 0,10 & 0,10 \\
\hline 2 & $\begin{array}{l}\text { Daya Manusia } \\
\text { Aparatur }\end{array}$ & 21 & 0,13 & 0,23 \\
\hline 3 & $\begin{array}{l}\text { Analis } \\
\text { Kependudukan } \\
\text { dan Pencatatan } \\
\text { Sipil }\end{array}$ & 36 & 0,23 & 0,46 \\
\hline & $\begin{array}{l}\text { Analis } \\
\text { Pengembangan }\end{array}$ & & & \\
\hline 4 & $\begin{array}{l}\text { Kapasitas } \\
\text { Keuangan } \\
\text { Daerah }\end{array}$ & 37 & 0,24 & 0,70 \\
\hline 5 & $\begin{array}{l}\text { Analis Tata } \\
\text { Praja }\end{array}$ & 47 & 0,30 & 1,00 \\
\hline & Jumlah & 156 & 1,00 & \\
\hline
\end{tabular}

$\mathrm{J}_{\mathrm{k}}(\mathrm{x})$ merupakan Distribusi kumulatif frekuensi, $\mathrm{D}_{\mathrm{t}}(\mathrm{x})$ merupakan Distribusi probabilitas frekuensi dan t dari 1 sampai $n$.

$$
\begin{aligned}
& \mathrm{J}_{1}=D p_{1}=0,10 \\
& \mathrm{~J}_{2}=D p_{2}+J_{1}=0,13+0,10=0,23 \\
& J_{3}=D p_{3}+J_{2}=0,23+0,23=0,46 \\
& J_{4}=D p_{4}+J_{3}=0,24+0,46=0,70 \\
& J_{5}=D p_{5}+J_{4}=0,30+0,70=1,00
\end{aligned}
$$

Tabel 3. Distribusi Kumulatif Penerimaan Latsar CPNS Tahun 2018

d. Menghitung interval penerimaan latsar CPNS sebagai range/ jangkauan untuk menentukan angka acak yang di ambil dari nilai distribusi probabilitas kumulatif yang dilihat pada Tabel 4. 
Faisal Roza, Sarjon Defit, Gunadi Widi Nurcahyo.

Tabel 4. Interval Penerimaan Latsar CPNS Tahun 2018

\begin{tabular}{|c|c|c|c|c|c|c|}
\hline \multirow[t]{2}{*}{ No } & \multirow[t]{2}{*}{ Jurusan } & \multirow{2}{*}{$\begin{array}{c}\text { Fr. } \\
2018 \\
\end{array}$} & \multirow[t]{2}{*}{$\mathrm{Dp}$} & \multirow[t]{2}{*}{$\mathrm{Dk}$} & \multicolumn{2}{|c|}{ Interval } \\
\hline & & & & & Awal & Akhir \\
\hline 1 & $\begin{array}{l}\text { Analis } \\
\text { Keungan }\end{array}$ & 15 & 0,10 & 0,10 & 1 & 10 \\
\hline 2 & $\begin{array}{l}\text { Analis } \\
\text { Sumber Daya } \\
\text { Manusia } \\
\text { Aparatur }\end{array}$ & 21 & 0.13 & 0,23 & 11 & 23 \\
\hline & $\begin{array}{l}\text { Analis } \\
\text { Kependuduka }\end{array}$ & & & & & \\
\hline 3 & $\begin{array}{l}\mathrm{n} \text { dan } \\
\text { Pencatatan } \\
\text { Sipil }\end{array}$ & 36 & 0,23 & 0,46 & 24 & 46 \\
\hline & $\begin{array}{l}\text { Analis } \\
\text { Pengembanga }\end{array}$ & & & & & \\
\hline 4 & $\begin{array}{l}\text { n Kapasitas } \\
\text { Keuangan } \\
\text { Daerah }\end{array}$ & 37 & 0,24 & 0,70 & 47 & 70 \\
\hline 5 & $\begin{array}{l}\text { Analis Tata } \\
\text { Praja }\end{array}$ & 47 & 0,30 & 1,00 & 71 & 100 \\
\hline & Jumlah & 156 & 1,00 & & & \\
\hline
\end{tabular}

e. Mengentri variable dan membangkitkan bilangan acak.

$$
\mathrm{F}_{\mathrm{e}+1}=\left(\mathrm{u} * \mathrm{~F}_{\mathrm{e}}+\mathrm{s}\right) \bmod i
$$

Dengan syarat $\mathbf{u}, \mathbf{s}<\mathbf{i}, \mathbf{F}_{\mathbf{0}}>\mathbf{0}$

Pada $\mathbf{F}_{\mathbf{e}}$ merupakan bilangan awal yang ditentukan, umerupakanKonstanta perkalian, $\mathbf{s}$ merupakan konstanta penambahan, mod merupakan modulus dan i adalah batasan nilai bilangan acak. Diketahui: $\mathrm{U}=5$; $\mathrm{F}_{0}=21 ; \mathrm{s}=3 ; \mathrm{I}=98$

$\mathrm{F}_{(1)}=(5 * 21+3) \bmod 98=(105+3) \bmod 98$ $=108 \bmod 98=10$

$\mathrm{F}_{(2)}=(5 * 10+3) \bmod 98=(50+3) \bmod 98$ $=53 \bmod 98=53$

$\mathrm{F}_{(3)}=(5 * 53+3) \bmod 98=(265+3) \bmod 98$ $=268 \bmod 98=72$

$\mathrm{F}_{(4)}=(5 * 72+3) \bmod 98=(360+3) \bmod 98$ $=363 \bmod 98=69$

$\mathrm{F}_{(5)}=(5 * 69+3) \bmod 98=(345+3) \bmod 98$ $=348 \bmod 98=54$

Tabel 5. Membangkitkan Bilangan Acak

\begin{tabular}{llcccc}
\hline No & \multicolumn{1}{c}{ Jurusan } & e & $\mathrm{Fe}$ & $\begin{array}{c}(\mathrm{U} * \\
\mathrm{Fe}+\mathrm{S})\end{array}$ & $\begin{array}{c}\mathrm{F}(\mathrm{e}+1)=(\mathrm{U} \\
* \mathrm{Fe}+\mathrm{S}) \mathrm{mod} 98\end{array}$ \\
\hline 1 & $\begin{array}{l}\text { Analis Keungan } \\
\text { Analis Sumber Daya }\end{array}$ & 0 & 21 & 108 & 10 \\
2 & $\begin{array}{l}\text { Manusia Aparatur } \\
\text { Analis }\end{array}$ & 10 & 53 & 53 \\
3 & $\begin{array}{l}\text { Kependudukan dan } \\
\text { Pencatatan Sipil } \\
\text { Analis }\end{array}$ & 2 & 53 & 268 & 72 \\
4 & $\begin{array}{l}\text { Pengembangan } \\
\text { Kapasitas Keuangan }\end{array}$ & 3 & 72 & 363 & 69 \\
5 & $\begin{array}{l}\text { Daerah } \\
\text { Analis Tata Praja }\end{array}$ & 4 & 69 & 348 & 54 \\
\hline
\end{tabular}

Tabel 5 menggambarkan bilangan acak yang telah di bangkitkan untuk penerimaan latsar CPNS.

f. Melakukan simulasi Monte Carlo.
Dalam melakukan simulasi Monte Carlo untuk memprediksi penerimaan latsar CPNS tahun 2019 dengan membandingkan pembangkit bilangan acak pada range/ jangkauan nilai interval angka yang telah diproses. Selanjutnya untuk dapat melihat tingkat akurasi percobaan simulasi penerimaan latsar CPNS dengan cara membandingkan nilai hasil percobaan simulasi tahun 2019 dengan data real 2019 dapat dilihat pada Tabel 6 .

$$
\mathrm{TA}=\mathrm{NK} / \mathrm{NT} * 100 \%
$$

TA merupakan tingkat akurasi, NK merupakan nilai terkecil dan NT merupakan nilai terbesar.

1. Analis Keuangan $=15 / 15 * 100 \%=100 \%$

2. Analis Sumber Daya Manusia Aparatur

$$
=20 / 37 * 100 \%=54 \%
$$

3. Analis Kependudukan dan Pencatatan Sipil

$$
=33 / 47 * 100 \%=70 \%
$$

4. Analis Pengembangan Kapasitas Keuangan Daerah

$$
=34 / 37 * 100 \%=92 \%
$$

5. Analis Tata Praja $=37 / 41 * 100 \%=90 \%$

Tabel 6. Hasil Simulasi Monte Carlo Penerimaan Latsar CPNS Purna Praja IPDN Tahun 2019

\begin{tabular}{llcccc}
\hline No & \multicolumn{1}{c}{ Jurusan } & $\begin{array}{c}\text { Angka } \\
\text { Acak }\end{array}$ & $\begin{array}{c}\text { Data } \\
\text { Simulasi } \\
2019\end{array}$ & $\begin{array}{c}\text { Data } \\
\text { Real } \\
2019\end{array}$ & $\begin{array}{c}\text { Persent } \\
\text { ase (\%) }\end{array}$ \\
\hline 1 & $\begin{array}{l}\text { Analis Keungan } \\
2\end{array}$ & 10 & 15 & 15 & 100 \\
& $\begin{array}{l}\text { Analis Sumber Daya } \\
\text { Manusia Aparatur }\end{array}$ & 53 & 37 & 20 & 54 \\
& $\begin{array}{l}\text { Analis Kependudukan } \\
\text { dan Pencatatan Sipil }\end{array}$ & 72 & 47 & 33 & 70 \\
4 & $\begin{array}{l}\text { Analis Pengembangan } \\
\text { Kapasitas Keuangan } \\
\text { Daerah }\end{array}$ & 69 & 37 & 34 & 92 \\
Analis Tata Praja & 54 & 37 & 41 & 90 \\
\hline & Rata-rata & & & & $\mathbf{8 1}$
\end{tabular}

Tabel 6 menjelaskan hasil simulasi Monte Carlo penerimaan latsar CPNS tahun 2019 diperoleh dari angka acak yang telah dibangkitkan sehingga tingkat akurasi rata-rata yaitu $81 \%$.

Tabel 7. Hasil Simulasi Monte Carlo Penerimaan Latsar CPNS Purna Praja IPDN Tahun 2020

\begin{tabular}{llcccc}
\hline No & \multicolumn{1}{c}{ Jurusan } & $\begin{array}{c}\text { Angka } \\
\text { Acak }\end{array}$ & $\begin{array}{c}\text { Data } \\
\text { Simulasi } \\
2020\end{array}$ & $\begin{array}{c}\text { Data } \\
\text { Real } \\
2020\end{array}$ & $\begin{array}{c}\text { Persentase } \\
(\%)\end{array}$ \\
\hline 1 & $\begin{array}{l}\text { Analis Keungan } \\
2\end{array}$ & 10 & 15 & 18 & 83 \\
& $\begin{array}{l}\text { Analis Sumber Daya } \\
\text { Manusia Aparatur }\end{array}$ & 53 & 34 & 23 & 68 \\
3 & $\begin{array}{l}\text { Analis Kependudukan } \\
\text { dan Pencatatan Sipil }\end{array}$ & 72 & 41 & 33 & 80 \\
4 & $\begin{array}{l}\text { Analis Pengembangan } \\
\text { Kapasitas Keuangan } \\
\text { Daerah }\end{array}$ & 69 & 34 & 32 & 94 \\
Analis Tata Praja & 54 & 34 & 43 & 79 \\
\hline & Rata-rata & & & & $\mathbf{8 1}$ \\
\hline
\end{tabular}

Tabel 7 menjelaskan hasil simulasi Monte Carlo penerimaan latsar CPNS tahun 2020 didapatkan dari 
angka acak yang dibangkitkan sehingga diperoleh rata-rata akurasi yaitu $81 \%$.

Tabel 8. Hasil Simulasi Monte Carlo Penerimaan Latsar CPNS Purna Praja IPDN Tahun 2021

\begin{tabular}{|c|c|c|c|}
\hline No & Jurusan & $\begin{array}{c}\text { Angka } \\
\text { Acak }\end{array}$ & $\begin{array}{c}\text { Data Simulasi } \\
2021\end{array}$ \\
\hline 1 & Analis Keungan & 10 & 18 \\
\hline 2 & $\begin{array}{l}\text { Analis Sumber Daya } \\
\text { Manusia Aparatur }\end{array}$ & 53 & 32 \\
\hline 3 & $\begin{array}{l}\text { Analis Kependudukan dan } \\
\text { Pencatatan Sipil } \\
\text { Analis Pengembangan }\end{array}$ & 72 & 43 \\
\hline 4 & $\begin{array}{l}\text { Kapasitas Keuangan } \\
\text { Daerah }\end{array}$ & 69 & 32 \\
\hline \multirow[t]{2}{*}{5} & Analis Tata Praja & 54 & 32 \\
\hline & Jumlah & & 157 \\
\hline
\end{tabular}

Tabel 8 mengambarkan hasil simulasi Monte Carlo penerimaan latsar CPNS tahun 2021 diperoleh dari angka acak yang telah dibangkitkan sehingga analis keuangan ada 18 peserta, analis sumber daya manusia aparatur ada 32 peserta, analis kependudukan dan pencatatan sipil ada 43 peserta, analis pengembangan kapasitas keuangan daerah ada 32 peserta dan analis tata praja ada 32 peserta.

\section{Kesimpulan}

Hasil pembahasan analisa dari penelitian ini didapatkan rata-rata akurasi $81 \%$ prediksi penerimaan latsar CPNS Purna Praja IPDN dengan menggunakan metode Monte Carlo. Sehingga dapat ditarik kesimpulan bahwa metode Monte Carlo ini cocok digunakan untuk penerimaan latsar CPNS pada PPSDM Regional Bukittinggi Kementerian Dalam Negeri dalam pengambilan keputusan penyelenggaraan pendidikan.

\section{Daftar Rujukan}

[1] Favre-Bulle, I. A. (2018). Light Scattering in Brain Tissue Using Monte Carlo Method. In Imaging, Manipulation and Optogenetics in Zebrafish, 9-20. DOI: https://doi.org/10.1007/978-3-319-96250-4_2 .

[2] Abishek, A., \& Nageswara Rao, B (2018). Reliability Study of Railway Bridge Circular Pier Using Monte Carlo Simulation. In Recent Advances in Structural Engineering, 2, 527-535.

[3] Nariyama, N. (2018). Monte Carlo Calculations of Skyshine Neutron Doses from an $18 \mathrm{MeV}$ Medical Linear Accelerator. In World Congress on Medical Physics and Biomedical Engineering, 529-531. DOI: https://doi.org/10.1007/978-98110-9023-3_95.

[4] Bacala, A. M. (2018). Monte Carlo Simulation of A Linac Using PRIMO: User-Friendly Educational Tool Which Can Be Taken To The Cloud For Free. In World Congress on Medical Physics and Biomedical Engineering, 851-854. DOI: https://doi.org/10.1007/978-981-10-9035-6_157 .

[5] Darnis, R., Nurcahyo, G. W., \& Yunus, Y. (2020). Simulasi Monte Carlo untuk Memprediksi Persediaan Darah. Jurnal Informasi dan Teknologi,2(4), 139-144. DOI: https://doi.org/10.37034/jidt.v2i4.98 .
[6] Santony, J. (2020). Simulasi Penjadwalan Proyek Pembangunan Jembatan Gantung dengan Metode Monte Carlo. Jurnal Informasi dan Teknologi,2(1), 30-35. DOI: https://doi.org/10.37034/jidt.v2i1.34 .

[7] Zalmadani, H., Santony, J., \& Yunus, Y. (2020). Prediksi Optimal dalam Produksi Bata Merah Menggunakan Metode Monte Carlo. Jurnal Informatika Ekonomi Bisnis, 2(1), 13-20. DOI: https://doi.org/10.37034/infeb.v2i1.11 .

[8] Mardiati, D., Defit, S., \& Nurcahyo, G. W. (2020). Simulasi Monte Carlo dalam Memprediksi Tingkat Lonjakan Penumpang (Studi Kasus di PT. Tri Arga Travel). Jurnal Informatika Ekonomi Bisnis, 2(3), 92-97. DOI: https://doi.org/10.37034/infeb.vi0.49

[9] Manurung, K. H., \& Santony, J. (2019). Simulasi Pengadaan Barang Menggunakan Metode Monte Carlo. Jurnal Sistim Informasi dan Teknologi, 1(3), 7-10. DOI: https://doi.org/10.35134/jsisfotek.v1i3.3 .

[10] Syahrin, E., Santony, J., \& Na'am, J. (2019). Pemodelan Penjualan Produk Herbal Menggunakan Metode Monte Carlo. Jurnal KomtekInfo, 5(3), 33-41. DOI: https://doi.org/10.35134/komtekinfo.v5i3.148

[11] Yusmaity, Santony, J., \& Yunus, Y. (2019). Simulasi Monte Carlo untuk Memprediksi Hasil Ujian Nasional (Studi Kasus di SMKN 2 Pekanbaru). Jurnal Informasi dan Teknologi, 1(4), 1-6. DOI: https://doi.org/10.37034/jidt.v1i4.21 .

[12]Fujimoto, R., Bock, C., Chen, W., Page, E., \& Panchal, J. H. (Eds.). (2017). Research Challenges In Modeling and Simulation For Engineering Complex Systems. Simulation Foundations, Methods, and Applications.

[13] Hutahaean, H. D. (2018). Analisa Simulasi Monte Carlo Untuk Memprediksi Tingkat Kehadiran Mahasiswa Dalam Perkuliahan (Studi Kasus: STMIK Pelita Nusantara). Journal of Informatic Pelita Nusantara, 3(1).

[14] Astia, R. Y., Santony, J., \& Sumijan, S. (2019). Prediction of Amount of Use of Planning Family Contraception Equipment Using Monte Carlo Method (Case Study In Linggo Sari Baganti District). Indonesian Journal of Artificial Intelligence and Data $\begin{array}{lll}\text { Mining, } & 2(1), & 28-36 .\end{array}$ http://dx.doi.org/10.24014/ijaidm.v2i1.5825 .

[15] Muhaimin, A., Sumijan, S., \& Santony, J. (2020). Pemodelan dan Simulasi Pengelolaan Persedian Alat Tulis Kantor dengan Metode Monte Carlo. Jaringan Sistem Informasi Robotik$J S R, 4(1), 1-6$.

[16] Iftitah, H., \& Yunus, Y. (2020). Prediksi Tingkat Penerimaan Lulusan Siswa Kejuruan dalam Dunia Usaha dan Industri Menggunakan Metode Monte Carlo. Jurnal Sistim Informasi dan Teknologi, 2(3), 84-89. https://doi.org/10.37034/jsisfotek.v2i3.71 .

[17] Satria, R., Sovia, R., \& Gema, R. L. (2017). Pemodelan dan Simulasi Analisa Sistem Antrian Pelayanan Nasabah di PT Sarana Sumatera Barat Ventura (SSBV) Menggunakan Metode Monte Carlo. Komputer Teknologi Informasi, 4(1). 